університету залізничного транспорту імені академіка В. Лазаряна Випуск 3. Дніпропетровськ 2012. С. 194-199.

17. О.Л. Закора, С.В. Ключник (ДІІТ), М. І. Величко, Г. О. Линник, М.П. Дитиненко, Д.Л, Івашкевич, О.А. Забіяка (ДП «Укрзалізниця») «Експериментально-теоретичні дослідження прогінної будови в процесі заміни мостового полотна» Мости та тунелі: теорія, дослідження, практика. Збірник наукових праць Дніпропетровського національного університету залізничного транспорту імені академіка В. Лазаряна Випуск 2. Дніпропетровськ 2012. С. 9-13.

DOI https://doi.org/10.30525/978-9934-26-046-9-52

\title{
ОЦІНКА РУХУ АВТОМОБІЛЬНОГО КОЛЕСА В СКЛАДНИХ УМОВАХ ЕКСПЛУАТАЦЇ̈
}

\author{
Петров Л. М. \\ кандидат технічних наук, доцент \\ Військова академія (м. Одеса) \\ м. Одеса, Украӥна \\ Петрик Ю. М. \\ старший викладач \\ Військова академія (м. Одеса) \\ м. Одеса, Україна \\ Борисенко Т. М. \\ магістр, \\ ведучий інженер-конструктор, механік \\ ТОВ «Телекарт-Прилад» \\ м. Одеса, Україна
}

Дорожні умови характеризуються параметрами місцевості, в якій експлуатується автомобіль, параметрами опорної поверхні, по якій він рухається, стабільність стану опорної поверхні, інтенсивністю та організацією руху. Деякі параметри дорожніх умов ( ті, якими визначається якість опорної поверхні ) можуть бути використані при конструюванні автомобілів та закладені в його експлуатаційні характеристики, а також при розробці окремих агрегатів та вузлів автомобіля. 
При розробці конструкції необхідно враховувати геометричні параметри профілю опорної поверхні, тобто кути підйомів або спусків та їі фізико-механічні характеристики.

Розглянимо рух автомобільного колеса при його зустрічі з рухливою перепоною, рис.1.

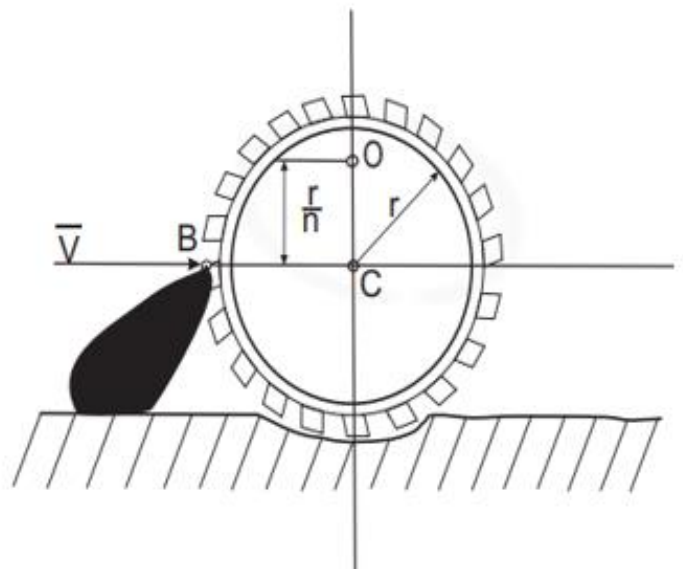

\section{Рис. 1. Схема зустрічі автомобільного колеса $з$ перепоною}

В результаті зіткнення автомобільного колеса 3 ушкодженням шляху відбувається перетворення енергії кочення автомобільного колеса в енергію перекочування його через перепону.

Приймемо припущення, що удар автомобільного колеса 3 перепоною відбувається непружним та опором шляху нехтуємо. Також приймемо за гіпотезу, що при ударі автомобільного колеса при переїзді через перепону виника\є миттєвий осередок обертання т. О.

Методика розрахунку.

1. Кутова швидкість обертання автомобільного колеса при його переїзді через перепону

Для знаходження кутової швидкості звернемося до теореми, яка описує виникнення кінетичного моменту під час удару автомобільного колеса у перепону [ 1, с.335-353]:

$$
L_{a}-L_{O}=\sum M[S]
$$

Згідно цієї теореми під час удару автомобільного колеса відносно миттєвої осі обертання змінюється кінетичний момент цілісної системи «автомобільне колесо-перепона». 
На рис.2 зображена система «автомобільне колесо-перепона» яка навантажена ударним імпульсом.



\section{Рис. 2. Навантаження «автомобільної системи-перепони» ударним імпульсом.}

Рівняння моментів під час удару автомобільного колеса 3 перепоною набуває вигляду:

$$
L_{a}-L_{O}=\sum M\left\lceil S_{O}\right\rceil
$$

Приймемо припущення що під час удару перепона набула швидкість $\mathrm{V}$, тоді кінетичний момент відносно осі т.О розглянутої системи набуває вигляду:

$$
L_{O}=\frac{P}{g} \cdot V \cdot \frac{r}{2}
$$

Після зіткнення автомобільного колеса 3 перепоною автомобільне колесо буде обертатися з кутовою швидкістю $\omega$ а перепона буде рухатись разом з автомобільним колесом (удар не пружний).

Отже:

$$
L_{\S}=L_{1}+L_{2}
$$

де $L_{1}=I_{1} \cdot \omega$ - кінетичний момент автомобільного колеса;

$=\cdot \omega-$ кінетичний момент перепони. 
Так як вісі обертання паралельні тому момент інерції автомобільного колеса визначаємо з формулою:

$$
I_{1}=\frac{Q}{g} \cdot \frac{r^{2}}{2}+\frac{Q}{g}\left(\frac{r}{2}\right)^{2}
$$

а момент інерції перепони визначаємо з формулою:

$$
I_{2}=\frac{P}{g}(\mathrm{OB})^{2}
$$

Підставивши (5) та (6) у формулу (4) отримуємо сумарний кінетичний момент інерції системи:

$$
L_{\Sigma}=\frac{r^{2}}{4 \cdot g}(5 \cdot P+3 \cdot Q) \cdot \omega
$$

Після підстановки формули (3) у формулу ( 7 ) формула для визначення кутової швидкості обертання системи «автомобільного колесаперепони» набуває вигляду:

$$
\omega=\frac{2 \cdot P \cdot V}{(5 \cdot P+3 \cdot Q)}
$$

Схема силового навантаження колісного рушія при перекочуванні його через перепону представлена на рис. 3 .

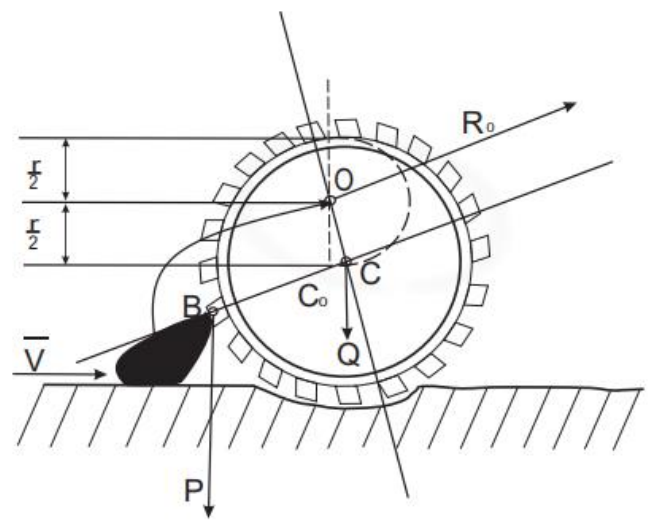

\section{Рис. 3. Схема силового навантаження колісного рушія при перекочуванні його через перепону}

На рис. 4 представлена Залежність кутової швидкості обертання системи»Автомобільного колеса - перепони» від ваги автомобільного колеса Q та сили зіткнення Р автомобільного колеса 3 перепоною 216 




Рис. 4. Залежність кутової швидкості обертання системи «Автомобільного колеса - перепони» від ваги автомобільного колеса $Q$ та сили зіткнення $P$ автомобільного колеса $з$ перепоною

Згідно рис. 4 можна зробити висновок, що швидкість перекочування автомобільного колеса через перепону в більшої степені впливає сила удару ніж вага автомобільного колеса.

\section{Література:}

1. Т.Б. Айзенберг, И.М. Воронков, В.М.Осецкий Руководство к решению задач по теоретической механике. Изд-во «Высшая школа», Москва, 1968.,-420с., С. 335-353. 